Seminário de Pesquisa

Programa de Pós-Graduação

Design FAU USP

\title{
Estado da arte do campo do design centrado em animais não humanos em 2020
}

\author{
Gabriella Ribeiro da Silva e Araujo, Luís Cláudio Portugal \\ do Nascimento
}

\author{
design centrado em usuários animais não humanos; design para \\ animais; design para usuários não humanos; ergonomia para animais \\ não humanos; design centrado no animal
}

Por meio de estudo preliminar, exploratório e qualitativo de reconhecimento, esta pesquisa de doutorado, em fase de desenvolvimento, objetiva compreender o estado da arte do segmento do design voltado para usuários constituídos por animais

Curso

Doutorado

\section{Linha de Pesquisa}

Teoria e História do Design

\section{Gabriella Ribeiro da Silva e Araujo}

Bacharel em Desenho Industrial pela Unopar (2010), Especialista em Gestão estratégica do design de moda pela Unisanta (2013) e Mestre em Têxtil e Moda pela Eachusp (2016). Atuou como docente em Moda na FMU-SP (2018) e, atualmente, cursa o Doutorado em Design na Fau-usp (2018).

e-mail: gabriellaaraujo@usp.br Lattes: http://lattes.cnpq. br/3054281432775380

Orcid: https://orcid.org/00000001-6306-4536

\section{Luís Cláudio Portugal \\ do Nascimento}

Professor da Fau-usp, doutor em ensino do design pela New York University (1997), mestre pela École Nationale Supérieure d'Arts et Métiers, Paris (1987), e bacharel em desenho industrial e comunicação visual pela Escola Superior de Desenho Industrial da Uerj (1983).

e-mail: claudioportugal@usp.br

Lattes: http://lattes.cnpq. br/2797773827825547

Orcid: https://orcid.org/00000003-4586-1747 não humanos. Mediante ampla taxonomia objetiva identificar, sistematizar e classificar as diferentes modalidades, nuances conceituais, finalidades, tipos de interface, classes de usuários e grupos de itens de design constitutivos deste segmento. Procura-se, também, mapear aspectos, tópicos e questões próprias a esta temática do design, analisando algumas de suas implicações mais características e específicas, no âmbito funcional, ergonômico, semiótico, ético, estético, histórico e/ou metodológico. Como fontes e técnicas de coleta de dados, a pesquisa vem se utilizando de buscas sistemáticas na internet, revisões bibliográficas, entrevistas pessoais semiestruturadas com especialistas no trato e comportamento animal, visitas a eventos envolvendo animais não humanos, bem como observações de situações práticas em clínicas veterinárias. Dentre os resultados preliminares obtidos, foi identificada a necessidade do desenvolvimento da disciplina de ergonomia voltada a animais não humanos, considerando-se que as características físicas, comportamentais e cognitivas de cada espécie não humana poderiam ser desconhecidas por não especialistas e/ou negligenciadas no projeto de design para esta classe de usuários. Ao término deste estudo, espera-se ampliar a compreensão teórica desta temática para o campo do design, contribuindo para aprimorar as práticas pedagógicas do campo, bem como para elevação da qualidade de projetos de design voltados para animais não humanos, beneficiando, potencialmente, também, esta classe mais peculiar de usuários. 


\title{
The State of the Art of Non-Human Animal-Centered Design in 2020
}

\author{
Gabriella Ribeiro da Silva e Araujo, Luís Cláudio Portugal \\ do Nascimento
}

non human centered design; design for animals; design for non human users; non human animals ergonomics; animal centered design

By means of a preliminary, exploratory qualitative study, this doctoral research, currently in its development stage, aims at establishing the state of the art of the segment of design geared toward users constituted by non-human animals. By way of devising an ample taxonomy of design products and services associated with non-human users, this research aims at identifying, systematizing and classifying the various modalities, conceptual shades, purposes, kinds of interface, classes of users and categories of different design items which form this particular segment. It also attempts to map aspects, topics, themes and issues inherent to this subject of design, analyzing some of its most characteristic and specific implications, in terms of its functional, ergonomic, semiotic, ethical, aesthetical, historical and methodological dimensions. Sources of data and data-collecting techniques encompass systematic

Line of Research

Design Theory and History

\section{Gabriella Ribeiro da Silva e Araujo}

Bachelor's degree in Industrial design from Unopar (2010), Postgraduate degree in Strategic management of fashion design from Unisanta (2013), Masters degree in Textile and Fashion from Each-usp (2016). Worked as a teacher at FMU-SP (2018) and currently is a PhD student in Design at Fau-usp (2018).

e-mail: gabriellaaraujo@usp.br

Lattes: http://lattes.cnpq. br/3054281432775380

Orcid: https://orcid.org/0000-

0001-6306-4536

\section{Luís Cláudio Portugal do} Nascimento

Professor at Fau-usp. He holds a Ph.D. in art education from New York University (1997), a Masters Degree from École Nationale Supérieure d'Arts et Métiers, Paris (1987), and a Bachelors Degree in Graphic and Industrial Design from Uerj's Escola Superior de Desenho Industrial (1983)

e-mail: claudioportugal@usp.br

Lattes: http://lattes.cnpq.

br/2797773827825547

Orcid: https://orcid.org/0000-

0003-4586-1747

Anais do 40 SPDesign - Seminário de Pesquisa do Programa de Pós-graduação em Design da FAU USP, São Paulo: Blucher, 2021. searches on the internet, literature reviews, in-depth semistructured interviews with a number of specialists in animal life, field trips to events featuring non-human animals, as well as direct observations of practical situations in veterinary clinics. Amongst the preliminary results already obtained, there is room for the creation of a discipline of ergonomics geared to non-human animals, taking into account physical, behavioral and cognitive traits of each non-human species. As a result of this study, the hope is to enlarge the theoretical understanding of this subject within the field of design, thereby contributing to improve pedagogical practices in the field, as well as improving the quality of design projects for nonhuman animals. 